\title{
Beal, Sophia: Brazil Under Construction. Fiction and Public Works. New York: Palgrave Macmillan, 2013.
}

Georg Wink ${ }^{1}$

O livro com o título sugestivo, que evoca tanto a problemática Arena da Baixada Paranaense, quanto, em termos mais filosóficos, o país do futuro em eterno devir, tem um duplo enfoque, revelado pelo subtítulo: por um lado, revisitar os ambiciosos projetos infraestruturais que os vários governos brasileiros realizaram durante o século XX, virando a atenção à sua carga simbólica, como emblemas de um país em progresso e veículos de um discurso oficial e pedagógico de modernização. Por outro lado, a representação destas obras na ficção, incluíndo obras literárias, textos jornalísticos, peças de teatro, letras de música e filmes, oscilando entre crítica e louvor. A ênfase repousa sobre a segunda perspectiva, conforme a formação principal da autora Sophia Beal, professora no departamento de Estudos Espanhóis e Portugueses da Universidade de Minnesota. O livro é baseado - embora não explicitamente - na investigação que a autora desenvolveu durante o seu doutoramento e segue uma abordagem orientada pelos Estudos Culturais e Poscoloniais.

Nas 198 páginas cativantes, escritas em prosa continuamente polida, Sophia Beal conduz o leitor, num tour d'horizon clássico, pelos canteiros de obras públicas e pelas Letras da Nação. Há várias perguntas que a guiam nesta viagem: O significado destas obras físicas para a construção de uma identidade nacional, como elementos de uma narrativa de integração simbólica do lendário vasto território numa unidade coesa. "What better metaphor for the cohesiveness of a nation than building bridges?", pergunta a autora (2013: 2), e o mesmo vale, evidentemente, para a malha rodoviária do

\footnotetext{
${ }^{1}$ Professor de Estudos Portugueses e Brasileiros da Universidade de Copenhaga.
}

Brasiliana - Journal for Brazilian Studies. Vol. 3, n.1 (July. 2014). ISSN 2245-4373. 
país, que "faz fluir, nas veias e artérias da Nação, a seiva do desenvolvimento" e "irriga de sangue os dedos de nossas mãos calejadas", para degustar algumas outras metáforas do discurso político recente, dos quais não posso evitar de lembrar-me espontaneamente. A outra pergunta foca o suplemento desta narrativa nacional de caráter pedagógica por vozes heterogêneas e, muitas vezes, dissonantes. Cabe às escritoras e aos escritores da nação de "resignificar" o discurso oficial, critica ou afirmativamente, para "flesh out the nuances of the government's public works initiatives with praise, satire, scorn, and imagination" (2013: 2). Obviamente, como a autora salienta, na maioria dos casos o benefício comum das obras ditas públicas não deixa de ser duvidoso, o que a leva a indagar, hipoteticamente: "Would public works stand for integration or oppression?" (2013: 2). Uma terceira dimensão da declaração de tese é a criação de um nexo, tanto no que concerne as obras em si, quanto os discursos que as representam, com a antiga questão da "originalidade" e da "alienação" da cultura brasileira e as suas várias interpretações (empresa que teria exigido a cogitação de uma discussão altamente complexa, a começar pela antropofagia cultural, que, possivelmente, excederia os limites da abordagem proposta).

A análize do objeto de estudo desenvolve-se em cinco partes, organizadas pela cronologia da realização das obras e seu tratamento literário. No segundo capítulo, "Conquering the Dark: Literature, Lighting, and Public Space in Rio de Janeiro in the Early 1900s", Sophia Beal aborda o processo de renovação urbana da então capital no início do século XX, inspirada no modelo do Paris depois das reformas hausmannianas, embora lembrado no Brasil como o grande "bota-abaixo". Como fenômeno paradigmático, a autora dá especial atenção à iluminação - uma vez mais: simbólica e prática, ou seja, o desassombramento e o uso da eletricidade - do espaço público e a exposição nacional de 1908, como vitrine de um país "civilizado", e a sua representação por textos jornalísticos e literários que oscilam entre a apologia (Olavo Bilac, e a revista 
Kósmos), a ambiguidade (João do Rio) e a crítica severa (Lima Barreto). No terceiro capítulo, "The Spectacle of Light: A Public Works Company in Southeastern Brazil (1906-1971)", analiza como os investimentos da empresa canadense Light no sistema de transporte e a geração de energia elêtrica serviram como uma fonte de inspiração para os escritores dos anos 20 e 30 (textos de Oswald de Andrade, Mário de Andrade e Patrícia Galvão, entre muitos outros, além de uma série de letras de música), época da industrialização incipiente no Brasil, mas também dos primeiros movimentos "nacionalistas". O capítulo número quatro, "Brasília: The Real and Promised City in 1960s Brazilian Literature", mostra, a base de textos de João Guimarães Rosa, Clarice Lispector e José Geraldo Vieira, como a nova capital serviu como plano de projeção para novas e antigas utopias de uma cidade ideal, mas também como a realidade frustrou as expectativas de uma nova época. O seguinte capítulo, "Fiction and Massive Public Works during the Brazilian Military Regime (1964-1985)", conhecidamente a época megalomaníaca em termos da ampliação infraestrutural, a autora focaliza dois projetos de alto prestígio: a ponte Rio-Niterói, inaugurada em 1974, e a BR 230, vulgo Transamazônica, inaugurada em 1972 (embora nunca completada). As obras faraônicas dos militares, apresentadas com tamboradas durante a primeira Semana Nacional de Transportes (1969), foram tematizados de forma bastante crítica. O exame aqui se concentra na peça O túnel de Dias Gomes, no filme Bye bye Brasil de Carlos Diegues e no conto "A maior ponte do mundo" de Domingos Pellegrini. O último capítulo, por fim, contempla a atualidade e - consequentemente, se nos lembrarmos das manifestações de junho e julho de 2013 - desliza o foco para ausência ou a falta de infraestrutura: “São Paulo's Failed Public Works in Ferrez's Capitão Pecado and Luiz Rufato's Eles Eram Muitos Cavalos". É o capítulo que mais abre espaço para a discussão dos limites da usufruição da infraestrutura pública, correlativo ao pleno exercício de cidadania. Um epílogo trata, de forma preliminar, das obras realizadas, principalmente no Rio de

Brasiliana - Journal for Brazilian Studies. Vol. 3, n.1 (July. 2014). ISSN 2245-4373. 
Janeiro, como preparativos aos grandes eventos esportivos, bem como de algumas das vozes críticas que as acompanham. Como a autora observa sagazmente, com isto se fecha um círculo que começou, um século atrás, com o lema "o Rio civiliza-se".

O livro, sem dúvida, é uma contribuição pertinente, tanto em relação ao pensamento social brasileiro, quanto à cultura brasileira do século XX. A idéia de partir das obras de infraestrutura, como fio condutor do livro, é muito convincente, pois permite introduzir o contexto histórico de forma compacta e, pela análise aprofundada dos textos - aliás, nem todos canônicos, alguns são pérolas esquecidas - tecer novas considerações sobre a história literária do Brasil. Neste sentido, o livro é um ótimo exemplo para a potencialidade dos Estudos Culturais. Há que se mencionar, nesta ocasião, que a argumentação do livro prescinde, em longos trechos, do recurso ao legado teórico habitual, e, pasmém, não deixa de ser menos evidente por isso; não obstante, quando é preciso referenciar um conceito ou uma teoria, a autora o faz com precisão e concisão. Algo inevitável é que a abordagem de "grande malhagem", que abrange todo um século e um corpus extenso, implique também numa certa brevidade de tratamento de questões de elevada complexidade. Ou, em outras palavras, quando se chega às conclusões, sobram alguns fios soltos. E sobram as grandes perguntas cujas respostas, para fazer justiça à autora, sequer tinham sido prometidas: O porquê do valor simbólico do Brasil em construção? E o porquê da preocupação literária com a construção? Para respondê-las, seria preciso retrilhar os caminhos da construção da Nação Brasileira na sua longue durée, considerando as pecularidades de sua formação inteira (o Brasil "Novo Mundo", "Sede da Corte”, "Império”, "país do futuro”, etc.), o que, obviamente, não foi o foco deste livro.

Alguns aspectos problemáticos às quais poderia-se fazer menção: A limitação rígida da perspectiva da autora em relação à infraestrutura apenas nacional é válida e reflete certo hábito acadêmico entre brasilianistas, mas talvez deixe passar 
despercebidos aspectos "transnacionais" que poderiam ter sido interessantes, como, p. ex., o telégrafo submarino transatlântico ou a invulgar ponte sobre o rio Oiapoque que ligará - pelo menos simbolicamente - o Brasil à França (provavelmente a partir de novembro de 2014). No que concerne a produção científica no Brasil, especialmente sobre a Primeira República, o livro de Sophia Beal dificilmente daria conta do estado da arte. Embora contemple a literatura subsidiária internacional, ignora a produção de vários autores brasileiros, especializados no assunto, que poderiam ter inspirado bastante a pesquisa, como, p. ex., Roberto Ventura, Nicolau Sevcenko, José Murilo de Carvalho e, sobretudo, a obra chave 1980-1914: no tempo das certezas (2000) de Angela Marques da Costa e Lilia Moritz Schwarcz, que muito diz respeito à eletrificação, a Light e a exposição mundial. Não da responsabilidade da autora, mas irritante, é a opção por notas finais em lugar de notas de rodapé; são mais de 80 observações, todas tão relevantes que mereceriam um lugar de mais destaque. Porém, esta "falha" da edição é contrabalançada pelo excelente índice remissivo.

Excetuando estas ressalvas, o livro proporciona uma leitura altamente recomendável para brasilianistas e pessoas com um interesse geral no Brasil, e praticamente obrigatória para quem quer ser introduzido às veredas do "processo civilizatório" e sua representação simbólica no Brasil.

Brasiliana - Journal for Brazilian Studies. Vol. 3, n.1 (July. 2014). ISSN 2245-4373. 